\title{
MONGOLIA AND ASIAN SECURITY
}

\section{P.Stobdan (India)}

We have approached the end of the twentieth century, which has been characterized by the unique paradox of unprecedented human progress and unprecedented destruction. On the one hand, rapid socio-economic changes have led to increased life expectancy by 18 years, and, as of 199580 per cent of all children had been immunized against vaccine-preventable childhood diseases. On the other hand, the percentage of civilian deaths resulting from war has risen sharply. It is estimated that over 110 million people died in 250 wars this century, which was roughly six times more than the estimated toll of wars in the nineteenth century.

\section{Changing Global and Regional Trends}

The momentous events in the last seven years signified the end of this dualistic nature of World War II. The unification of the two German states, freedom gained by the East European states and the dissolution of the superpower USSR have been the landmark events delineating the end of an era in world history. These events have also been attributed as portents, passing through a time which is exceptionally interesting but also fraught with danger.

Following the collapse of the bipolar format of international politics, the nations with great ambitions are trying to give the new world order a shape of their own design. Attempts are being made to rewrite ideologies, the old alliances are in search of new orientation, political systems, national sovereignties, and national frontiers, are being confronted with new challenges. While few are trying to resist this change, others are compelled to be mere observers, and there are still others, due to their limitations, unable to act swiftly to guard their interests in a fast changing global environment. In this new post-Cold War circumstance, many would view the present as a great opportunity lo drastically revise and improve the prospects for peace and security. However, the debate over what kind of global order may emerge is far from complete. The final result will shape the nature and prospects of peace and security in, the next century.

With the bipolarity shattered in most respects (except perhaps in nuclear relations), none of the other familiar alternative characterizations of international systems, such as unipolarity, tripolarity, multi-polarity, offer an adequate description of the fast changing international environment. 
The present world could certainly not accurately be described as univocal. The United States with its mighty military force could not afford even to fight Iraq by itself. We have witnessed how the Americans passed their begging bowl around the world to pay for the war. As there is more diffusion of power, at least in economic terms, the US surely would be unwilling, if not unable, to fight such a war again without equal support from allies.

The world is neither accurately characterized as multicolor. Under this framework, there must be three or more relatively equal centers of power competing and balancing. In a military sense the world is certainly not multicolor. But from the economic point of view, it could be characterized as tri-polar (the United States, Japan and the European Community). However, the possibility does exist of increasing economic frictions among its three spilling over into political spheres, undermining international peace and security. There is, however, a limitation to this structure as many East Asian nations will be loath to live under the regional dominance of Japan. Besides, heavy dependence on Middle East oil remains a major incentive for constraint on the three economic poles to move toward autarchy.

What has been witnessed, however, as the inevitable side-effect of the collapsed system of Cold War bipolarity, is the emergence of a series of regional centers of power asserting themselves autonomously in one area or an other. This hypothesis as a basis of the international system is being appropriately described as polycentric ${ }^{1}$. This structure is based on an asymmetric power paradigm which includes states that may be considered current and future great powers. Decisions on major international issues are no longer taking place in Washington and Moscow alone. Even in its general weakness, Russia still maintains a colossal amount of military capability, including nuclear weapons, exceeding that of any country other than the United States. Japan is in the midst of debate to decide the pros and cons of matching its mighty economic clout with a reinvigorated military-political establishment. The European Community is still in the process of achieving its historic goal of establishing the European Union while coping with the struggling southern European problems. Europe still has some time to act effectively as a foreign policy or military unit. China, on the other hand, has Asia's largest military force but does not have the capacity to be effective militarily much beyond its borders. China have too has to some more time to acquire an effective economic credibility. Similarly, India with its large techno-economic power base has become a significant power, at least in the South Asian region. It had acquired the status of an important international player even during the bipolar system. 
Under the poly-centric system, the centers of power are nonhierarchical, where the leading group include the United States, the European Union, Japan, and Russia, with China and India both moving into great power position.

There have been several new concepts formulated to explain the future trend of development in the aftermath of the Cold War. Among others, it was theorized and accepted by many that this end of polar confrontation, largely between democracy and totalitarianism, will minimize the role of ideology in international relations and conflict. It was further claimed that the end of the Cold War marked the "end of history"2. However such a paradigm has not proved correct as we still see palpable types of dualism not only in Asia but also in Europe. Instead, there have been spurt of various types of nationalism and authoritarianism all over. There are also religiously based ideologies which are trying to fill the ideological vacuum in the post-Cold War era.

Following the end of the dualistic world order, it appeared for a while that a defeated Russia would display the type of contrition shown by Germany in 1945 - which it would confess past wrong deeds, disown its past successes and take refuge under the Western community. For a while, Russia also assumed that it would get the necessary financial support from the West to start a functioning market economy. For a short time in Russia too, then, prevailing rhetoric called for the need to shed the "imperial obligation" and "historical baggage". In fact, the political centre around the time of Soviet collapse, apart from denouncing Communism, renounced the territorial burden, in favor of a complete "spiritual and physical" salvation of the Russian people. The radical prescription for a Russian renewal included the absolute right of the non-Slav republics to secede from the Soviet Union. It was enough to indicate to the nonSlavs that, if they hesitated, the Slav republics would make the break themselves. A declaration on 8 December, 1991, to form a "Slavic Union" of the Ukraine, Belarus and Russia was in conformity with a nationalistic rhetoric. A relationship, therefore, was observed between an increase in Russian nationalism and a decline in "great power thinking." This affected both the greatness (glories) of Tsarist Russia, and the patriotism of the Soviet kind. A logical question, such as "did Russia grow poorer from its separation from Poland and Finland," and the example of Japan's economic growth after the renunciation of international missions and political adventure made Russia eager to part with regions such as Central Asia. Some Russians thought it was thoughtlessly conquered by Alexander II. In return, the Euro-centric Russian view envisaged a rapid integration of Russia into the political and economic realms of the Western world. 
Six years have passed since then, there is little to signify a strategic shift taking place in that direction. Notwithstanding the broad division of opinion and at times confusion in the overall parameters of debate on Russia's postCold War policy, it has demonstrated more than once that Russia will not allow the power vacuum in post-Soviet space to be filled by outside interest groups. Regardless of what the foreign policy orientation of Russia might have been in the last half decade, the core issue of Russia's vital national interest was safeguarded instead by more traditional and dynamic institutions of Russia's Defense, Security and Internal Affairs organs. Through a hard headed doctrine, the Russian military carried out a sustained and coherent policy to retain geo-political interests throughout the "near abroad." This made many Western analysts realize their mistake to have assumed the statements from one branch of the Russian government represented the intention of the whole.

Russia's irreconcilable interest in Central Asia and Tran Caucasus is no more explicit than its efforts to retain its monopoly over the oil industry in the region. In fact, oil has become a powerful instrument for Russia to regulate and assert its renewed national interest in Central Asia and Tran Caucasus. In the changed circumstances oil is getting closely intertwined with the dynamics of politics, ethnicity, religion and security in the post-Soviet space. Henry Kissinger noted recently that new Russia, even under Yeltsin, has made adventurism domination and produced insecurity for all its neighbors, even at the moment of Russia's maximum weakness ${ }^{3}$. For the West it appears that the initial fear of Central Asian states falling prey to Islamic fundamentalism was unfounded. Likewise, the euphoria that Russia will get integrated into the Western value system, ultimately turned out to be naive and misleading.

There are others who believed that the world will increasingly be divided along civilization entities and conflicts in the future will be between civilizations ${ }^{4}$. This theory is also unrealistic as it tends to underplay the role of nations and nationalism. Such a concept appeared to have been attributed in the rise of Islam. But Islamic world too strongly divided to pose any significant challenge to others. Moreover, Islamic resurgence must be seen in political rather than in terms of civilization.

The end of the ideological confrontation has in fact given way to the resurfacing of localized conflicts based on ethnic tensions, resurgent nationalism and religious extremism. This new pattern of conflicts has a direct bearing on international peace and security. The decomposition has not stopped at the door of the Cold War, but also brought down the entire pre-Cold War edifice. 
The de-communization has led not only to the disappearance of the Soviet Union but has also caused ethnic cleansing in most East European and former Soviet states. Of the 18 armed conflicts in Europe in 1989 to 1993, 15 were fought on the territories of the former Soviet Union and Yugoslavia.

The end of ideological confrontation between Islam and Communism has not brought peace in Afghanistan. The Mujaheedins finally got divided into Tajik and Pushup camps. Today battles are fought along ethnic, regional, sectarian and even tribal lines. This is true in the case of Tajikistan, where underlying confrontation has been between tribal groups. The loyalties to clans and subclans appear to be more important than politics or even religion.

One of the most widespread features of the Third World since World War II has been the expansion of the state in both its spatial and policy realms. The end of the Cold War has further increased the number of sovereign states. The regimes, which hitherto had displayed only limited capacity outside their core regions, have sought increasingly systematic control over peripheral areas through administration, armies and education. As a result, there has been growing centrifugal tendencies, often generating separatist pressures, which in many cases have triggered violent majority-minority conflicts. Therefore, if we see a world pattern of casualties, only 50 percent of war casualties were civilians at the beginning of this century, whereas by the 1980s this percentage had risen to 74. But the current estimates of civilian casualties in the conflict of the 1990s is said to be running over 90 per cent.

The above trend of war casualties also indicates that interstate wars have been replaced by intra-state conflicts. This is a new type of conflict generally identified as non-standard or "irregular war" where the force is projected by using the method of guerrilla warfare, insurgencies and terrorism. Those types of conflict are often carried out through proxy wars, with a large element of external involvement. In 1993, there were as many as 36 major wars, primarily of this nature, in progress across the world. The ongoing civil war in Afghanistan is a classic case of intra-state conflict. If the mechanisms to prevent such possible conflicts are not evolved, Central Asian states too will fall victim to this phenomenon.

Associated with this phenomenon is the growing Tran nationalization of ideologies, which are being sought or imposed through violent means and at times through revolutionary movements such as the Taliban. What is happening in Afghanistan at present is no different from similar exports of revolution, particularly during Communist days. A similar ideological claim is likely to be made over Central Asian states. 
In the changed circumstances, the conflicts based on religious, civilization or national elements have given the outside powers enough opportunities to enhance their role as interventionists for peace. Such intervention is also sought to capture and control the vital strategic resources that are needed for the developed world.

The fall of a polarized world structure on the other hand generated a sense of insecurity among countries. The luxury of inaction enjoyed by many states during the Cold War has become a thing of the past. Today the margins for political maneuver as well as frictions have widened. As a result, states are faced with a new type of uncertainty. Already the concept of sovereignty has been challenged severely. The possibility of increasing fragmentation of states has gone up and so has the new types of interventionism. This has particularly heightened the concerns of the plural slates. Defense and security no longer remain associated terms. Security problems are no longer systematically linked and identified with any politico-military player. Even in Europe, there is probably a greater feeling of insecurity than during the Cold War. The rationale behind the reunification of Europe is the absolute necessity to share the cost of maintaining security. However, the Western world still tries to keep security as a military concept. In other spheres, it is not being allowed to grow further, except the elementary need to ensure the regular supply of oil to the Western world. In the coming century, the greatest challenge will be to ensure that security is being perceived in a much wider and holistic sense which will ensure peace and the development of mankind on an enduring basis.

Although it is hard to project international peace and security for the future, there are certain basic issues which should bind the interests of the entire world community.

1. Must make continuous effort to accelerate the process of arms control and disarmament (conventional, nuclear, chemical, and biological) at global, regional, and sub-regional levels.

2. Must find a cooperative mechanism for a durable international peace and security

3. Need to restructure and strengthen the United Nation's ability to defend international peace and security

4. Develop a well-coordinated strategy to counter international terrorism, drug trafficking and other forms of international piracy

5. Evolve a global modus operandi to tackle the vital issues involving political and economic refugees and other displaced persons fleeing the impact of regional crises, 
6. Adopt a global plan for equal distribution of world resources, as well as, even development of mankind.

7. Establish global standards of behavior, human rights protection, and non-aggression based on respect for the inviolability of international frontiers.

\section{Inner Asian Dynamism}

The re-emergence of five republics in the Inner Asian world has generated a wave of strategic debate, which raised diverse issues pertaining to both opportunities and challenges of the post-Cold War era. They range from ideological issues to the systemic problems of nation building, economic change, and ecological crises, democratization and human rights, ethno nationalism and religious revivalism, terrorism and weapons proliferation, territorial integrity and security issues, et al.

The emergence of Central Asian states as well as the issues relating to the region has a profound impact on the entire region of Inner Asia. Notwithstanding the historical background, efforts exist to evolve a fresh conceptual framework for the post-Soviet space in Asia. Many gloomy scenarios have already been drawn for the future geo-political orientation of these post-communist states. Several interested powers are trying to seek legitimating and affinity along historical, geographical, ethnic and religious lines.

Questions are being raised whether 70 years of Soviet rule was really a divisive colonizing drive or a progressive nationalizing process that bestowed national profiles for distinct ethnic groups in inner Asia. Since these identities have not vanished on their own after the Russian retreat, efforts are being made to unmask what others describe as the pseudo-Soviet-culture in order to restore the 1400 year old Irano-Turkic Islamic culture.

Since the question of inner Asian identity is a complex one deeply rooted like an onion with centuries of different layers, the process of re-identification is not going to be easy. While some favor the status quo national frame, others are searching for a new synthesis. When many talk about reviving ancient Turkistan nationhood, others are keen to sharpen it along transnational religious ideology. The subject is getting more complex as outside actors are moving in with clear agendas. They are doing so by either exploiting the ethnic divisions or arousing Islamic sentiments. If one tries to fill in the security vacuum, others are captioning on the region's economic disorder and spiritual gap.

Notwithstanding the outward similarities with Europe, the impact of the end of Cold War on Asia has not been the same. 'The absence of a popular 
rhetoric for region's liberation aside, there is no parallel model for political unification - an attraction Western Europe offered for East Europe. Suffice it to say that ethnic resurgence in Inner Asia was responsible for the Soviet collapse. The Islamic world was not only divided but also too outdated for emulate instantly.

Interestingly, the debate in the West, even prior to the Soviet collapse, had indicated a larger Western agenda for the Asiatic part of the Soviet sphere then the immediate goal of containing Communism. If Communism was the only problem then there should have been peace in Afghanistan. Therefore, the significance of debate about the region by the maxima list school in the West becomes important. From the American perspective, the regional setting of Central Asia has never been confined to the five republics of the former Soviet Union, but included a wider view on both lands and peoples traditionally not part of the four major settled regions of Asia-Russia, China, India and Persia. What they termed as "inner Asia" included a vast nomadic civilization lying on the fringes of "the major settled world. The metaphors of Eurasia, Inner Asia, Greater Central, Silk Route etc., are being coined to conceptualize and break the region from controlling powers. Already from two, Afghanistan and Mongolia till 1991, the number of independent states in "Inner Asia" has now increased to seven. From no where in the East of Moscow and the North of Beijing the US has now diplomatic presence in the entire Eurasian belt.

The unraveling of Inner Asian ethnic frontiers, reviving cultural contacts and move towards regional consolidation is going to be the future trend. The growing Uzbek and Tajik factor in Afghanistan, the Kazakh factor in China and Mongolia, the Islamic factor in Chechnya, Tatars tan, Booshkoristan, Kashmir, the Buddhist/Mongol factor in Buryatia, Tuva, Khalmyki etc. are signs of emerging geo-political upheaval in "inner Asia".

Many would see this phenomenon as part of the Western strategy to undermine Russia, China and India. Some even suspect it as a conspiracy against Iran, which has large ethnic minorities, such as 16 million Azeris a number more than the population* of Azerbaijan itself. People seeking solution to Afghanistan imbroglio see the unraveling of ancient division- treating Northern Afghanistan as an extension of Tajikistan and Uzbekistan as the only way out, whereas recognizing Kabul and south of the Hindu-kush mountains as a thorn in the side of Pakistan.

As the popular notion of Central Asia falling prey to Iranian led Islamic fundamentalism remains unfounded, and the capacity of Turkey offering as a 
countervailing model for the region remains unrealistic, the US is gradually forging its own strategic equations in the region. Lately it has been trying to find land routes access to the region. Recent US moves in Central Asia and Afghanistan, must be seen in the backdrop of firstly-Russian unwillingness to part away with Central Asia resource and secondly the Indo-Iranian joint initiative for closer cooperation in the region. The phenomena of Taliban's advancement in Afghanistan and Unocal oil/gas pipeline issue are not outside these developments.

Interestingly, after having undermined the military potential of Kazakhstan, Washington is now keen to see Uzbekistan as the only candidate for regional anchor. In fact, Uzbekistan is likely to outpace Pakistan as the key strategic partner of the US. From the US point of view, not only Uzbekistan historically qualifies to be a complete state but would potentially become the Turkey of Asia.

On the other hand strategic circumstances make Russia loath to give up its traditional rights in Central Asia despite all the confusion in Moscow, Turkey is still looking for fraternal ties with the region, China has already made enough commercial penetration, fulfilling Central Asia's immediate needs. Iran seeks to dispel its image of trouble shooter while talking only in economic language with Central Asians, Pakistan and Saudi Arabia have shown interest in fostering their own narrow sectarian dominance there.

Amidst this confusion, the states in the region are adopting their individual postures. Each one's corresponds to their potential and capacities, intensity of ethnic divisions and religious sentiments. Same is also true for their military strength. Whereas democracy has not made much impact on their polity. Kazakhstan's concerns stems from its Russian Diaspora in its northern provinces, compelling Nazarbaev to talk about the "third option" based on the European model of integration. Uzbekistan's initiative for a UN supported "permanent seminar" is aimed at neutralizing Russian influence in the region. For Tajikistan the choice is either to disappear as a state or to extend its present boundaries to become the must powerful country in the region. Turkmenistan's effort at distancing itself away from the rest is worrisome for others. It's posture of "positive neutrality" advocate close ties with Russia but does not approve the CIS. It is close to Turkey but understands the importance of Iran; it is close to Pakistan but sensitive to India's concern. Threatened by inter-clan rivalries and religious extremism Khirgizstan is preparing for an "open society" inviting diverse elements as a balancing force to contain problems. 
Among conflicting issues oil is going to remain critical commodity of strategic importance. In fact, the conflict situations in region will move along the oil/ gas pipelines. The ethnic issues are more complex than it appears. The Uzbeks are every where. There are more Tajiks in Afghanistan than in Tajikistan. Besides Tajik's core centers are located in Uzbekistan. There are more Pushdowns in Pakistan than in Afghanistan. 80 percent of Central Asian national boundaries are said to have been drawn arbitrarily. Sharing of water would be source of interstate conflict. Uzbekistan is already a full military power. Whereas hydrocarbon rich Turkmenistan with 4 million people will depend on outside power like in the case of Kuwait for its national security. The economic disparity owing to varying resource potentials will widen their differences as well as increase outside power for intervention. The ideological and spiritual disorientation among the people, increasing corruption, prostitution, moral bankruptcy, problems associated with migration flow, drug trafficking and arms proliferation at el will bring Central Asia on the central focus of political, economic and military conflict by the beginning of next century.

There exist a host of problems ranging from territorial to ethnic disputes and dispute over land and natural resources will potentially destabilize not only Central Asia also the neighboring regions. Any destabilizing factor in one state will impinge on the others. Conflict within one state could spill across the border, as already been demonstrated in the case of Tajikistan and Afghanistan. The ecological imbalances, such as to shrinking of Aral Sea will have region wide implications. Disruption in irrigation and water distribution system could entail a serious destabilizing potential. Already a battle has been started over finding preferable oil and gas pipelines as well as communication routes to link with the international network.

Given the arbitrary territorial divisions, cutting across ethnic enclaves, inter-ethnic fights in the region will have a destabilizing affect on a large scale. In fact, the intra-tribal confrontations are likely to be more serious than the intertribal and inter regional rifts. Tajikistan provides a clear example, where clans from distinct regions become enemies and make alliances in the pursuit of wealth and power. This is the case in Afghanistan too, where inter and intra-ethnic/ tribal conflicts have become the major factor of instability. The end of ideological confrontation between Islam versus communism has not necessarily brought about peace in that country. The regional and tribal base conflicts have seriously undermined common religious identity. 


\section{Role for Mongolia}

In this complex strategic environment, Mongolia as one of the oldest nations in world, whose influence pervaded not only in its immediate vicinity in Inner Asia, but also in European and East Asian affairs in the pre-modern period, once again going to play the central role in shaping of geopolitical order in Asia. The heartland of a fierce nomadic empire, however, got reduced to become a pawn in the Russian and Chinese geopolitics in the modem times. However, the end of the Cold War has fundamentally altered the position of Mongolia in the international politics. The 19th/20th Century buffer zone concept has no validity for Mongolia any longer. Neither the geopolitics of today can be understood in the context of controlling outlying border areas. The role Mongolia played during the Sino Soviet confrontation has been obviously crucial, but today the dynamics of international relations is much more complex than it used to be. There are number of important factors which makes Mongolia's role significant for new order in Inner Asia.

1. The historical and civilization aspect of the Mongols as the leader of the Turkic world should allow Mongolia to revive its sense of geopolitical responsibilities in the region,

2. The geographical position at the cross junction of Central Asia, Northeast Asia, Far East, China and Russia, makes Mongolia strategically most significant country in Asia.

3. The ethnic aspects of the spread of Mongol Diaspora across Asian increases Mongolia's role as cultural stabilizer in Asia,

4. The Buddhist cultural background of the Mongols, not only ensures durable peace, but also has a neutralizing effect on the complex cultural and political contradictions across Asia.

5. Mongolia will continue to have moderating political influence on the Sino-Russian relations, as well as, on the relations among states in Inner Asia. The growing strategic proximity between Russia and China, by no means removes the contradiction on their frontiers. The forays of Chinese immigration into the Russian Far East has already begun to threaten Russian security. The Chinese are going to score more long term benefits than Russia out of present strategic axis.

6. Mongolia's future challenge may emanate from the:enormous political uncertainties within both China and Russia. Any and of political diffusion in the two neighboring countries will entail circumstances that could nurture a pan-Mongolism movement across Inner Asia. 
7. As China is going to rise to the position of a super power, ;he confrontation between it and the dominant power the United States, is bound to increase, Mongolia's role in moderating conflicts between the two will become significantly important. Both internally and from the external point of view, changes in the coming years will demand Mongolia to make a major shift from its Russia-centric policies to China oriented policies.

8. Consequently, Mongolia will also play a balancing role even in the security situation of South Asia. From India's perspective, Mongolia has a great strategic importance in counter balancing Chinese adventurism in Asia. Besides, India has the highest stake in the cultural resources of Mongolia.

9. Mongolia's location on the vicinity of resource rich Siberia will enhance its strategic importance for the industrialized countries to have benign political and economic presence, 10. Mongolia wills importance in forestalling ideological spread, such as Islamic fundamentalism across Asia.

\section{Notes}

1. Jasjit Singh, "Managing Regional Security", Asian Strategic Review, 1992-93, New Delhi, 1993.p. 7

2. Fukuyama F., "The End of History". The National Interest, 1989, Nol6

3. Henry Kissinger, "Beware. A Threat Abroad", Newsweek, June 17, 1996

4. Samuel P. Huntington, "The Clash of Civilizations, What?" Foreign affairs, November-December, 1993, pp. 191-92. 